\title{
GEGURITAN DUKUH SILADRI KAJIAN NILAI PENDIDIKAN KARAKTER
}

\author{
Oleh : \\ Ni Wayan Arini
}

\begin{abstract}
Abstrak
Sastra Bali tradisional merupakan bagian dari kebudayaan Bali yang sekaligus merupakan peninggalan leluhur yang tak ternilai harganya. Di samping itu juga sastra tradisional Bali merupakan salah satu bentuk yang dapat digunakan sebagai media dalam menuangkan gagasan-gagasan maupun ide-ide untuk menyampaikan ajaran-ajaran atau norma-norma dalam kehidupan bermasyarakat. Karya sastra merupakan salah satu peninggalan nenek moyang suatu masyarakat yang kaya akan nilai- nilai pendidikan, kecerdikan, kritik sosial serta mengandung nilai budi pekerti yang luhur yang sudah sepantasnya mendapatkan perhatian dalam usaha untuk melestarikan dan mengembangkan nilai budaya bangsa, khususnya budaya bahasa Bali. Sebuah karya sastra pasti terkandung nilai- nilai kehidupan yang ber;laku pada masyarakat di mana karya sastra tersebut diciptakan. Seperti misalnya nilai- nilai tersebut menggambarkan norma, tradisi, aturan dan kepercayaan yang dianut/ dilakukan pada suatu masyarakat. Nilai- nilai tersebut antara lain, nilai moral, nilai sosial; nilai budaya/ tradisi: nilai religi/ keagamaan, dan lain sebagainya. Demikian pula halnya dengan geguritan Dukuh Siladri yang banyak sekali mengandung nilai-nilai pendidikan karakter yang dapat diajarkan kepada anak-anak, remaja maupun orang dewasa untuk dijadikan pedoman berperilaku dalam kehidupan sehari-hari. Nilai -nilai pendidikan karakter yang terdapat dalam Geguritan Dukuh Siladri adalah nilai-nilai : 1) rasa ingin tahu, 2) cinta damai, 3) bersahabat/komunikatif, 4) gemar membaca, 5) jujur, 6) kerja keras, 7) Tanggung Jawab, 8) peduli social, dan 9) religious.
\end{abstract}

Kata Kunci : Geguritan Dukuh Siladri, Nilai Pendidikan Karakter.

Abstract

Traditional Balinese literature is part of Balinese culture which is also a priceless ancestral heritage. In addition, traditional Balinese literature is one form that can be used as a medium in pouring ideas to convey the teachings or norms in the life of society. Literary work is one of the ancestral heritages of a society which is rich in educational values, ingenuity, and social criticism and contains noble virtues that deserve attention in an attempt to preserve and develop the cultural values of the nation, especially the language culture of Bali. A literary work must contain the values of life that apply to the society in which the literary work was created. Such values, for example, represent norms, traditions, rules and beliefs held in a society. These values are, among others, moral values, social values; cultural values / traditions: religious values / religious, and so forth. Similarly, geguritan Dukuh Siladri contains a lot of character education values that can be taught to children, adolescents and adults to be a guide to behave in everyday life. The values of character education contained in Geguritan Dukuh 


\section{PENDAHULUAN}

Sastra Bali tradisional merupakan bagian dari kebudayaan Bali yang sekaligus merupakan peninggalan leluhur yang tak ternilai harganya. Di samping itu juga sastra tradisional Bali merupakan salah satu bentuk yang dapat digunakan sebagai media dalam menuangkan gagasangagasan maupun ide-ide untuk menyampaikan ajaran-ajaran atau norma-norma dalam kehidupan bermasyarakat. Karya sastra merupakan salah satu peninggalan nenek moyang suatu masyarakat yang kaya akan nilai- nilai pendidikan, kecerdikan, kritik sosial serta mengandung nilai budi pekerti yang luhur yang sudah sepantasnya mendapatkan perhatian dalam usaha untuk melestarikan dan mengembangkan nilai budaya bangsa, khususnya budaya bahasa Bali.

Kesusastraan Bali dapat ditinjau dari dua segi yaitu secara fungsional dan secara struktural. Secara fungsinya yang termasuk kesusastraan Bali adalah karya-karya sastra Jawa Kuna yang difungsikan sebagai milik masyarakat Bali. Sedangkan secara struktural yang dapat dikatagorikan sebagai kesusastraan Bali yang karya-karya sastranya hanya berbahasa Bali (Agastia, 1980: 8).

Banyak cara yang dilakukan seorang pengarang untuk menuangkan isi pikiran serta gagasannya, salah satunya adalah dengan cara menulis sebuah karya sastra. Karya sastra tradisional yang banyak mengandung nilai-nilai yang dapat dijadikan tuntunan dalam kehidupan salah satunya ada yang disebut dengan geguritan.

Agastia (1980 : 1) mengatakan geguritan sebagai salah bentuk karya sastra Bali klasik yang kelahirannya mula-mula disebabkan besarnya pengaruh bahasa Kawi, sehingga hasil yang tampak adalah dengan bahasa Bali-Kawi yang memakai bentukbentuk morfologis atau kata-kata bahasa Bali. Karya sastra geguritan sangat erat hubungannya dengan kebudayaan Bali, hal ini terbukti dengan adanya ungkapan-ungkapan seperti : "Sastra Bali sebagai aspek kebudayaan Bali, Sastra Bali sebagai penunjang kebudayaan Bali, sastra Bali sebagai cermin kebudayaan Bali”.

Geguritan sebagai bentuk karya sastra tradisional mempunyai konvensi sastra konvensi sastra tertentu, bahkan sistem konvensi yang dimilikinya cukup ketat. Geguritan dibentuk oleh pupuh-pupuh yang diikat oleh syarat tertentu yang disebut dengan "pada lingsa", yaitu banyaknya suku kata dalam tiap-tiap baris, banyaknya baris dalam tiap-tiap bait dan bunyi akhir dalam tiap-tiap baris (Agastia, 1980 : 16-17.

Geguritan erat kaitannya dengan seni pentas, bahkan memiliki pengaruh yang sangat besar terhadap seni tari seperti arja, prembon, drama gong, topeng, dan sebagainya. Karena tarian arja, prembon dan topeng menggunakan pupuh sebagai media utama untuk berkomunikasi. Dengan demikian, geguritan dapat digunakan selain sebagai hiburan, juga digunakan sebagai perantara dalam menyampaikan pesan-pesan yang mengandung ajaran-ajaran dalam menunjang pendidikan.

Pendidikan merupakan hal yang sangat penting dalam kehidupan manusia, serta tidak dapat dipisahkan dari kehidupannya. Mengingat sangat pentingnya pendidikan terhadap kehidupan manusia, maka pendidikan harus dilaksanakan sebaik-baiknya sehingga memperoleh hasil sesuai dengan yang diharapkan. Dan pelaksanaan pendidikan dimulai dari 
pendidikan di lingkungan keluarga (informal), pendidikan di lingkungan sekolah (formal), dan pendidikan di lingkungan masyarakat (non formal) yang dikenal dengan sebutan dengan Tri Pusat Pendidikan.

Ahmadi ( 2001 : 92) mengatakan kepribadian atau personalitas bukanlah merupakan hal yang diwarisi, yang diperolehnya dari keturunan, tetapi personalitas itu adalah hasil resultants daripada proses interaksi sosial secara fundamental antara individu dengan individu yang lain dengan seluruh pola kebudayaan yang ada di sekitar individu-individu, baik materiil maupun non materiil, baik individual maupun sosial. Manusia dilahirkan di dalam masyarakat mempunyai tata hidup dan penghidupan serta pola tingkah laku yang kompleks.

Pendidikan karakter, saat ini masih sangat hangat dibicarakan karena akhir-akhir ini terjadi degradasi moral yang banyak terjadi di masyarakat yaitu perilaku-perilaku yang tidak baik seperti mabukmabukan, geng motor, seks bebas, penggunaan narkoba, tawuran dan sejenisnya. Selanjutnya menurut Ratna Megawangi (2004:95) mengatakan pendidikan karakter adalah sebuah usaha untuk mendidik anak-anak agar dapat mengambil keputusan dengan bijak dan mempraktikkannya dalam kehidupan sehari-hari, sehingga mereka dapat memberikan kontribusi yang positif kepada lingkungannya. Definisi lain yang dikemukakan oleh Fakry Gaffar (dalam Amirulloh Syarbini, 2012 : 17)) mengatakan pendidikan karakter adalah sebuah proses transformasi nilai-nilai kehidupan ditumbuhkembangkan kepribadian seseorang, sehingga menjadi satu dalam perilaku kehidupan orang itu.
Pada umumnya pendidikan karakter menekankan pada keteladanan, penciptaan lingkungan, dan pembiasaan. Dengan demikian, apa yang dilihat, didengar, dirasakan dan dikerjakan oleh anak dapat membentuk karakter mereka. Selain menjadikan keteladanan dan pembiasaan sebagai metode pendidikan utama, penciptaan iklim dan budaya serta lingkungan yang kondusif juga sangat penting, dan turut membentuk karakter anak-anak.

Sebuah karya sastra pasti terkandung nilai- nilai kehidupan yang ber;laku pada masyarakat diman karya sastra tersebut diciptakan. Seperti misalnya nilai- nilai tersebut menggambarkan norma, tradisi, aturan dan kepercayaan yang dianut/ dilakukan pada suatu masyarakat. Nilai- nilai tersebut antara lain, Nilai moral, Nilai Sosial; nilai budaya/ tradisi: Nilai religi/ keagamaan, dan lain sebagainya. Geguritan juga dibangun oleh sebuah struktur. Struktur geguritan itu disusun dan dibina oleh unsur- unsur karya sastra sehingga merupakan satu kesatuan yang menarik, yang diistilahkan sebagai Intrinsik dan Ekstrinsik. Yang termasuk unsur Inrinsik adalah judul karangan, tema karangan, alur cerita, tokoh atau penokohan/pelaku dan pesan atau amanat. Sedangkan yang termasuk unsur Ekstrinsik yaitu unsur luar karya sastra, seperti siapa pengarang karya sastra tersebut atau biografi Sang Pengarang dan alasan atau yang melatarbelakangi penulisan karya sastra tersebut. Unsur mampu memahami apa yang tersirat dan tersurat. Kalau tidak dibaca terlebih dahulu tidak akan mengetahui makna yang ada dalam karya sastra tersebut. Apalagi membaca sambil menyanyikan pupuh yang membangun akan semakin dipahami maksud dan tujuan yang ada 
dalam karya sastra geguritan.

Demikian pula halnya dengan geguritan Dukuh Siladri yang banyak sekali mengandung nilai-nilai yang dapat ditransformasikan kepada anakanak, remaja maupun orang dewasa untuk dijadikan pedoman berperilaku dalam kehidupan sehari-hari. Dengan demikian, peneliti tertarik untuk mengadakan penelitian yang berjudul “ Nilai-Nilai Pendidikan Karakter yang terkandung dalam Geguritan Dukuh Siladri”.

\section{PEMBAHASAN}

\subsection{Pengertian Nilai}

Poerwadarminta (1993 : 440) dinyatakan nilai dapat diartikan sebagai harga, rata-rata, kadar (banyak sedikitnya isi), mutu dan sifat-sifat (hal-hal) yang penting atau berguna bagi kemanusiaan. Nilai merupakan kegunaan dan pelajaran terpenting serta pesan yang terkandung dalam sesuatu. Di samping itu, nilai juga dapat diartikan sebagai sesuatu yang luhur dan mulia.

Yudibrata (1982 : 104) mengatakan nilai adalah tingkatan kebijaksanaan atau kebaikan yang dimiliki sesuatu. Suatu nilai memang diturunkan melaluipersepsi seseorang mengenai sesuatu yang luhur dan manusiawi, yang kegunaannya yang praktis.

Louis O Kattsof (dalam Djunaidi Ghoni, 1982 : 15) mengatakan bahwa nilai itu mempunyai empat macam arti, yang terdiri atas : (1) bernilai artinya berguna, (2) merupakan nilai, artinya baik atau benar atau indah, (3) mengandung nilai, artinya merupakan obyek atau keinginan atau sifat yang menimbulkan sikap setuju serta suatu predikat, (4) memberi nilai, artinya memutuskan bahwa sesuatu itu diinginkan atau menunjukkan nilai.

Dengan demikian, nilai berarti sesuatu yang berharga, atau penting dalam kehidupan masyarakat, untuk memberikan arah kehidupan manusia tentang apa yang benar, berharga, dan berguna bagi kehidupan manusia.

\subsection{Pendidikan Karakter}

Dewasa ini pendidikan karakter bangsa juga mencakup pendidikan budi pekerti. Untuk mencapai karakter bangsa yang diharapkan, diperlukan indidividu-individu yang memiliki karakter dan atau budi pekerti yang baik. Oleh karena itu, dalam upaya pembangunan karakter bangsa diperlukan upaya yang sungguhsungguh untuk membangun karakter individu.

Wynne (dalam Mulyasa, 2012 : 3) mengemukakan bahwa karakter berasal dari bahasa Yunani yang berarti " to mark " (menandai) dan memfokuskan pada bagaimana menerapkan nilai-nilai kebaikan dalam tindakan nyata atau perilaku seharihari. Oleh sebab itu, seseorang yang berperilaku tidak jujur, curang, kejam, dan rakus dikatakan sebagai orang yang memiliki karakter jelek, sedangkan yang berperilaku baik jujur, dan suka menolong dikatakan sebagai orang yang memiliki karakter yang baik/mulia. Jadi, istilah karakter erat kaitannya dengan personality (kepribadian) seseorang, di mana seseorang bisa disebut orang yang berkarakter (a person of character ) jika tingkah lakunya sesuai dengan kaidah moral.

Poerwadarminta, (1996: 521) mengatakan secara etimologi, kata karakter berarti tabiat, watak, sifatsifat kejiwaan, akhlak atau budi pekerti yang membedakan seseorang 
dengan orang lain.

Sejalan dengan pendapat tersebut, Dirjen Pendidikan Agama Islam Kementrian Agama Republik Indonesia (dalam Mulyasa, 2012 : 4) mengemukakan bahwa karakter (character) dapat diartikan sebagai totalitas ciri-ciri pribadi yang melekat dan dapat diidentifikasi pada perilaku individu yang bersifat unik, dalam arti secara khusus ciri-ciri ini membedakan antara satu individu dengan yang lainnya. Karena ciri-ciri karakter tersebut dapat diidentifikasi pada perilaku individu dan bersifat unik, maka karakter sangat dekat dengan kepribadian individu. Dengan demikian, istilah karakter berkaitan erat dengan personality (kepribadian) seseorang, sehingga ia bisa disebut orang yang berkarakter (a person of character) jika perilakunya sesuai dengan etika atau kaidah moral.

Doni Koesoema (2007 : 80) menjelaskan bahwa seseorang sering mengasosiasikan karakter dengan apa yang disebut temperamen yang memberinya definisi yang menentukan unsur psikososial yang dikaitkan dengan pendidikan dan konteks lingkungan. Selain itu, juga bisa memahami karakter dari sudut behavior yang menekankan unsur somatopsikis yang dimiliki individu sejak lahir. Di sini istilah karakter sama dengan kepribadian. Kepribadian dianggap sebagai ciri atau karakteristik atau gaya atau sifat khas dari seseorang yang bersumber dari bentukan-bentukan yang diterima dari lingkungan, misalnya keluarga pada masa kecil dan juga bawaan seseorang sejak lahir.

Sunarta (dalam Amirulloh Syarbini, 2012 : 14) mengatakan karakter adalah ciri khusus dari struktur dasar kepribadian seseorang (watak). Sedangkan watak yang diperoleh (character acquired) merupakan atribut seseorang yang perkembangannya berasal dari sumber lain di luar dirinya oleh karena berhubungan dengan lingkungan alam atau sosial. Karakter juga dapat diartikan personality bagi individu.

Dari berbagai pendapat itu dapat ditarik kesimpulan bahwa karakter adalah sifat yang mantap, stabil dan khusus yang melekat dalam pribadi seseorang yang membuatnya bersikap dan bertindak secara spontan, tidak dapat dipengaruhi oleh keadaan dan tanpa memerlukan pemikiran terlebih dahulu.

Dari konsep karakter ini muncul istilah pendidikan karakter ( character education). Di Indonesia, istilah pendidikan karakter mulai diperkenalkan sekitar tahun 2005-an. Hal itu secara implisit ditegaskan dalam Rencana Pembangunan Jangka Panjang Nasional (RPJPN) tahun 2005 - 2015, di mana pendidikan karakter ditempatkan sebagai landasan untuk mewujudkan visi pembangunan nasional, yaitu "mewujudkan masyarakat berakhlak mulia, bermoral, beretika, berbudaya, dan beradab berdasarkan Falsafah Pancasila".

Pendidikan karakter adalah “" pendidikan nilai, pendidikan budi pekerti, pendidikan moral, dan pendidikan akhlak yang bertujuan mengembangkan kemampuan peserta didik untuk memberikan keputusan baik-buruk, memelihara apa yang baik dan mewujudkan kebaikan itu dalam kehidupan sehari-hari dengan sepenuh hati" (Amirulloh Syarbini, 2012: 16).

Ratna Megawangi (2004 : 95) mengatakan pendidikan karakter adalah sebuah usaha untuk mendidik anak-anak agar dapat mengambil keputusan dengan bijak dan mempraktekkannya dalam kehidupan sehari-hari, sehingga mereka dapat 
memberikan kontribusi yang positif kepada lingkungannya. Definisi lain dikemukakan oleh Fakry Gaffar (dalam Amirulloh Syarbini, 2012 : 17) mengatakan pendidikan karakter adalah sebuah proses transformasi nilai-nilai kehidupan untuk ditumbuhkembangkan dalam kepribadian seseorang, sehingga menjadi satu dalam perilaku kehidupan orang itu.

Lebih lanjut Lickona (dalam Mulyasa, 2012 : 4) menegaskan bahwa pendidikan karakter yang baik harus melibatkan bukan saja aspek "knowing the good", tetapi juga " desiring the good " atau "loving the good" dan "acting the good", sehingga manusia tidak berperilaku seperti robot yang diindroktrinasi oleh paham tertentu. Di sini ditekankan pentingnya tiga komponen karakter yang baik (components of good character) yaitu moral knowing atau pengetahuan tentang moral, moral feeling atau perasaan tentang moral dan moral action atau tindakan moral. Ketiga komponen tersebut perlu diperhatikan dalam pendidikan karakter, agar anak mampu melaksanakan ajaran-ajaran tersebut kehidupan sehari-hari nilai-nilai kebajikan itu secara utuh dan menyeluruh.

Atas dasar itu, pendidikan karakter bukan sekedar mengajarkan mana yang benar dan mana yang salah, tetapi lebih dari itu, pendidikan karakter menanamkan kebiasaan (habituation) mengenai hal mana yang baik, sehingga anak akan menjadi paham (kognitif) tentang mana yang benar dan salah, mampu merasakan (afektif) nilai yang baik dan biasa melakukannya (psikomotorik).

Sehingga dapat dikatakan, pendidikan karakter harus melibatkan bukan saja aspek pengetahuan yang baik baik (moral knowing), akan tetapi juga dapat atau mampu merasakan dengan baik (moral feeling ), serta mampu menunjukkan suatu tindakan atau perilaku yang baik (moral action ). Dengan demikian, pendidikan karakter menekankan pada habit atau kebiasaan yang secara terus-menerus dipraktekkan dan dilakukan.

Answar (2013 : 112)

mengatakan secara psikologis karakter individu dimaknai sebagai hasil keterpaduan empat bagian, yaitu :

1. Olah hati : berkenaan dengan perasaan sikap dan keyakinan/ keimanan.

2. Olah pikir : berkenaan dengan proses nalar guna mencari dan menggunakan pengetahuan secara kritis, kreatif, dan inovatif.

3. Olah Raga : berkenaan dengan proses persepsi, kesiapan, peniruan, manipulasi, dan penciptaan aktivitas baru disertai sportivitas.

4. Olah Rasa dan karsa : berkenaan dengan kemauan dan kreativitas yang tercermin dalam kepedulian, pencitraan, dan penciptaan kebaruan.

Selanjutnya Kemdikbud merilis beberapa nilai-nilai pendidikan karakter sebagaimana terlihat dalam tabel berikut ini : 


\begin{tabular}{|c|c|}
\hline Religius & $\begin{array}{l}\text { Sikap dan perilaku yang patuh dalam melaksanakan ajaran } \\
\text { agama yang dianutnya, toleran terhadap pelaksanaan ibadah } \\
\text { agama lain, dan hidup rukun dengan pemeluk agama lain. }\end{array}$ \\
\hline Jujur & $\begin{array}{l}\text { Perilaku yang didasarkan pada upaya menjadikan dirinya } \\
\text { sebagai orang yang selalu dapat dipercaya dalam perkataan, } \\
\text { tindakan dan pekerjaan. }\end{array}$ \\
\hline Tole & $\begin{array}{l}\text { ikap dan tindakan yang menghargai perbedaan agama, suku, } \\
\text { tnis, pendapat, sikap, dan tindakan orang lain yang berbeda } \\
\text { ari dirinya. }\end{array}$ \\
\hline Disi & $\begin{array}{l}\text { indakan yang menunjukkan perilaku tertib dan patuh pada } \\
\text { erbagai ketentuan dan peraturan. }\end{array}$ \\
\hline Kerj & $\begin{array}{l}\text { Perilaku yang menunjukkan upaya sungguh-sungguh dalam } \\
\text { mengatasi berbagai hambatan belajar dan tugas, serta } \\
\text { menyelesaikan tugas dengan sebaik-baiknya. }\end{array}$ \\
\hline Kreatif & $\begin{array}{l}\text { erpikir dan melakukan sesuatu untuk menghasilkan cara atau } \\
\text { asil baru dari sesuatu yang telah dimiliki. }\end{array}$ \\
\hline$\overline{\text { Man }}$ & $\begin{array}{l}\text { ikap dan perilaku yang tidak mudah tergantung pada orang } \\
\text { in dalam menyelesaikan tugas-tugas. }\end{array}$ \\
\hline Dem & $\begin{array}{l}\text { Cara berpikir, bersikap, dan bertindak yang menilai hak dan } \\
\text { kewajiban dirinya dan orang lain. }\end{array}$ \\
\hline $\begin{array}{l}\text { Rasa ingin } \\
\text { tahu }\end{array}$ & $\begin{array}{l}\text { Sikap dan tindakan yang selalu berupaya untuk mengetahui } \\
\text { lebih mendalam dan meluas dari sesuatu yang dipelajarinya , } \\
\text { dilihat dan didengar. }\end{array}$ \\
\hline $\begin{array}{l}\text { Sem } \\
\text { keba }\end{array}$ & $\begin{array}{l}\text { Cara berpikir, bertindak, dan berwawasan yang menempatkan } \\
\text { kepentingan bangsa dan negara di atas kepentingan diri dan } \\
\text { kelompoknya. }\end{array}$ \\
\hline $\begin{array}{l}\text { Cinta } \\
\text { Tanah Air }\end{array}$ & $\begin{array}{l}\text { Cara berpikir, bersikap, dan berbuat yang menunjukkan } \\
\text { kesetiaan, kepedulian dan penghargaan yang tinggi terhadap } \\
\text { bahasa, lingkungan fisik, sosial, budaya, ekonomi, dan politik } \\
\text { bangsa. }\end{array}$ \\
\hline $\begin{array}{l}\text { Mengharga } \\
\text { i prestasi }\end{array}$ & $\begin{array}{l}\text { Sikap dan tindakan yang mendorong dirinya untuk } \\
\text { menghasilkan sesuatu yang berguna bagi masyarakat, dan } \\
\text { mengakui serta menghormati keberhasilan orang lain. }\end{array}$ \\
\hline $\begin{array}{l}\text { Bersi } \\
\text { komı } \\
\mathrm{f} \\
\end{array}$ & $\begin{array}{l}\text { Tindakan yang memperlihatkan rasa senang berbicara, bergaul } \\
\text { dan bekerja sama dengan orang lain. }\end{array}$ \\
\hline $\begin{array}{l}\text { Cinta } \\
\text { Damai }\end{array}$ & abkan orang lain \\
\hline $\begin{array}{l}\text { Gemar } \\
\text { membac }\end{array}$ & bagai bacaan \\
\hline $\begin{array}{l}\text { Peduli } \\
\text { lingkungan }\end{array}$ & $\begin{array}{l}\text { Sikap dan tindakan yang selalu berupaya mencegah kerusakan } \\
\text { pada lingkungan alam di sekitarnya dan mengembangkan upaya } \\
\text {-upaya untuk memperbaiki kerusakan alam yang sudah terjadi. }\end{array}$ \\
\hline $\begin{array}{l}\text { Peduli } \\
\text { Sosial }\end{array}$ & $\begin{array}{l}\text { Sikap dan tindakan yang selalu ingin memberi bantuan pada } \\
\text { orang lain dan masyarakat yang membutuhkan. }\end{array}$ \\
\hline $\begin{array}{l}\text { Tanggung } \\
\text { Jawab }\end{array}$ & $\begin{array}{l}\text { Sikap dan perilaku seseorang untuk melaksanakan tugas dan } \\
\text { kewajibannya, yang seharusnya dia lakukan, baik terhadap diri }\end{array}$ \\
\hline & 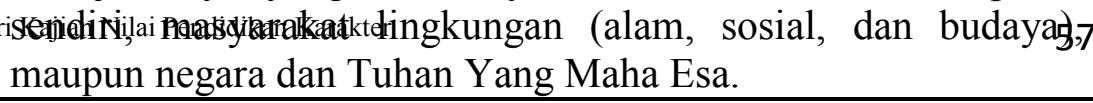 \\
\hline
\end{tabular}




\section{Puskur Kemdikbud, Pengembangan halaman 9-10.}

Dari uraian di atas dapat disimpulkan bahwa yang dimaksud dengan pendidikan karakter adalah suatu proses internalisasi atau penanaman nilai-nilai yang positif kepada anak agar anak-anak memiliki karakter yang baik (good character) sesuai dengan nilai-nilai yang dirujuk, baik dari agama, budaya, maupun falsafah bangsa.

\section{Geguritan}

Secara etimologi geguritan berasal dari kata gurit yang berarti gubah, karang, sadur atau gubahan. Kata gurit mendapat akhiran -an kemudian menjadi guritan yang berarti gubahan, saduran, karangan. Kata guritan mengalami proses perulangan suku kata awal atau proses perulangan dwi purwa menjadi geguritan yang berarti karangan cerita yang berbentuk tembang (Warna, 1991 : 223).

Geguritan merupakan salah satu kesusastraan Bali tradisional yang dibentuk dengan pupuh-pupuh yang diikat oleh beberapa konvensi yang biasa disebut pada lingsa. Secara etimologi geguritan berasal dari kata gurit. Dalam bahasa Jawa Kuna 'gurit" berarti "tulis" menjadi anggurit yang artinya menulis ke dalam bentuk puis. Agastia (1980:3) menyatakan geguritan adalah suatu karya sastra tradisional atau klasik yang mempunyai sistem konvensi tertentu yang cukup ketat. Suatu geguritan biasanya terbentuk dari beberapa tembang atau pupuh. Tiaptiap tembang atau pupuh diikat oleh beberapa kaidah (pada lingsa) yang harus diperhatikan oleh setiap pengawi (pengarang).

Dari uraian tersebut dapat disimpulkan bahwa geguritan berarti hasil karangan atau saduran cerita, yang berbentuk puisi atau syair yang menggunakan tembang atau pupuh. Dengan demikian dalam membaca geguritan tidaklah seperti membaca prosa, tetapi harus sesuai dengan syarat-syarat irama dari masingmasing pupuh.

Sedangkan dalam Kamus Bahasa Bali (1986 : 48) menjelaskan bahwa kata dukuh berarti padukuhan atau ashrama. Sedangkan sila berarti duduk dan adri berarti gunung. Jadi Dukuh Siladri berarti padukuhan atau ashrama yang bertempat di gunung. Jadi dapat disimpulkan Geguritan Dukuh Siladri bahwa hasil karangan atau saduran cerita, yang berbentuk puisi atau syair yang menggunakan tembang atau pupuh.dalam cerita tersebut mengisahkan tentang seseorang yang tinggal di ashrama atau padukuhan untuk belajar atau menuntut ilmu pengetahuan.

\subsection{Nilai-Nilai Pendidikan Karakter yang terkandung dalam Geguritan Dukuh Siladri}

Karakter diajarkan dengan mengenalkan, memahamkan hingga mengajak anak sehingga pada akhirnya mereka mampu mempraktekkan dan memaknainya sebagai sesuatu yang melekat dan menjadi tindakan perenungan (reflective action) serta mengembangkannya menjadi pusat keunggulan insani (center of human excellence). Proses pengembangan nilai-nilai yang menjadi landasan dari karakter itu menghendaki suatu proses yang berkelanjutan (Asmaun Sahlan, 2012: 14).

Kemendikbud (dalam Asmaun Sahlan, 2012 : 14) membedakan beberapa istilah yang memiliki kedekatan makna antara kepribadian dengan karakter. Adapun beberapa 
istilah tersebut antara lain : (a) personality (kepribadian)

penggambaran tingkah laku secara deskriptif tanpa memberi nilai, (b) character (karakter) : penggambaran tingkah laku dengan menonjolkan nilai baik secara eksplisit maupun implisit, (c) disposition (watak) : karakter yang telah lama dimiliki dan sampai sekarang belum berubah, (d) temperament (temperamen)

kepribadian yang berkait erat dengan determinan biologik atau fisiologik, (e) traits (sifat) : respons yang senada (sama) terhadap sekelompok stimuli yang mirip, berlangsung dalam kurun waktu yang relatif lama, (f) typeatribute (ciri) : mirip dengansifat, tetapi dalam kelompok stimuli yang lebih terbatas, (g) habit : kebiasaan respons yang sama cenderung berulang untuk stimulus yang sama pula.

Dengan demikian dapat dikatakan bahwa muara dari berbagai pengertian yang mengemuka dalam mengartikan pendidikan karakter menyiratkan pesan bahwa pendidikan karakter tidak hanya dijadikan salah satu pilar pedoman untuk berprilaku bagi umat manusia secara keseluruhan, akan tetapi juga mampu mendorong segenap manusia untuk konsisten melaksanakan nilai-nilai pendidikan karakter di manapun berada.

Pendidikan karakter mampu mengantarkan seseorang untuk belajar memaknai dan menghargai kearifan lokal. Walaupun secara pisik dan psikhis seseorang belum mengerti mengenai hal tersebut, namun jika melihat bahwa esensi pendidikan pada hakikatnya adalah peniruan (imitasi) dan pembiasaan sehingga kearifan lokal sangat perlu dikenalkan sejak dini.

Berkenaan dengan hal tersebut, geguritan Dukuh Siladri merupakan salah satu kearifan lokal yang kaya akan nilai-nilai yang dapat dijadikan pedoman untuk berprilaku. Adapun nilai-nilai pendidikan karakter yang terkandung dalam Geguritan Dukuh Siladri adalah sebagai berikut :

\subsubsection{Rasa Ingin Tahu}

Rasa ingin tahu merupakan sikap dan tindakan yang selalu berupaya untuk mengetahui lebih mendalam tentang sesuatu yang dipelajarinya, dilihatnya, dirasakannya, maupun yang didengarnya. Dalam cerita ini tokoh I Siladri dengan I Made Kirti yaitu membicarakan tentang maksud I Siladri untuk menuntut ilmu kepada Empu Dibiyaja di Gunung Kawi, karena I Siladri merasa bodoh sehingga harus banyak belajar agar mampu menjalani kehidupan. Hal tersebut dapat dilihat pada kutipan di bawah ini:

Beli belog jrih pisan/
pacang meiyegan ring cahi/
kranannya beli mangalah/
nanging beli saking asih/
da cahi salah tampi/
mangaden beli mangambul/
satingkah beline luwas/
ka Gunung Kawi ne jani/
ento kasub/
pasraman Empu Dibiyaja//
(Dukuh siladri, puh Sinom, hal 2
bait 9)
Terjemahan :
Kakak bodoh dan takut sekali/
akan bertengkar denganmu/
itulah sebabnya kakak mengalah/
tapi kakak karena sayang/
janganlah kamu salah paham/
mengira kakak minggat/
perbuatan kakak pergi/
ke Gunung Kawi sekarang/
yang termasyur/
tempat pertapaan Empu Dibiyaja//
Dalam kutipan di atas, jelas
ali nampak adanya rasa ingin tahu


dari I Siladri sehingga ia rela pergi dari kampung halamannya menuju Gunung Kawi untuk menuntut ilmu kepada Mpu Dibiyaja yang termasyur.

\subsubsection{Cinta Damai}

Rasa cinta merupakan sikap, perkataan dan tindakan yang menyebabkan orang lain merasa senang dan aman atas kehadiran dirinya. Untuk dapat membuat orang lain merasa nyaman, sebagai individu dalam melakukan setiap perkataan maupun perbuatan hendaknya dipikirkan matang-matang sehingga tidak menyinggung perasaan orang lain. Geguritan Dukuh Siladri dari awal sampai akhir cerita yang ditonjolkan tentang pendidikan atau ajaran-ajaran cinta damai yang patut dijadikan pedoman dalam kehidupan. Hal tersebut dapat dilihat pada kutipan dibawah ini:

Ne jani bli mawekas/
masih mituturin ring cahi/
da ngagu jedig ring anak/
dewek cahine kenehin/
apang da anake juari/
mahang ucap tan rahayu/
anak sangka jua matingkah/
melah jele sami uning/
da kadurus/
ngawenang anake rusak//
(Dukuh siladri, puh Sinom, hal
2 bait 11 )
Sikute tuara da dija/
deweke suba mangisi/
angdenya mamik-amikan/
uyah muang calagi/
rasannya sami uningin/
wiadin teda bareng satus/
tuara bina pangrasanya/
keto pangrasanya cahi/
yan matingkah/
kenehin malu pastiang//
(Dukuh siladri, puh Sinom, hal

2 bait 12)

Terjemahan:
Saat ini kakak berpesan/

lagi menasehati dirimu/

jangan sombong dan dengki pada orang lain/

renungkanlah pada diri sendiri/

agar orang lain merasa malu/

untuk berkata-kata kotor kepadamu/ begitujuga dalam bertingkah laku/

baik atau buruk semua orang tahu/ janganlah membuat orang lain menjadi rusak//

Cerminnya bukanlah dimana-mana/ sudah ada pada diri sendiri/ bagaikan memakan makanan/ garam maupun buah asam/ rasanya semua diketahui/ sekalipun dimakan bersama orang banyak/

tidaklah berbeda yang dirasakan/ begitu juga perasaanmu/ kalau bertingkah laku/ pikirkanlah dulu dengan baik//

Bila diperhatikan kutipan tersebut di atas nampak sekali adanya unsur pendidikan. Dan unsur pendidikan tersebut berupa nasehatnasehat agar tidak berbuat dengki pada orang lain agar orang lain tidak berani berkata-kata kotor kepada diri dan bertingkah laku pikirkanlah dulu dengan baik. Dengan berperilaku yang baik tersebut otomatis akan menimbulkan rasa cinta damai dalam pergaulan.

Di sisi lain juga Ni Kusumasari memberikan nasehat kepada $\mathrm{Ni}$ Klinyar bahwa dari dalam diri katakatanya yang keluar dan akan ke dalam diri pula ia akan kembali. Begitu juga kalau selamat atau baik ia keluar maka kembalinyapun ia dengan selamat atau baik. Dan maka kalau jelek keluarnya maka jelek pula kembalinya/ datangnya. Hal tersebut dapat dilihat pada kutipan berikut :

Ring awak munyine pesu/ tuah ka awak tuwine mulih/ 
rahayu reko pesunyal

mulih rahayu mabalik/

yan jele pesunya kocap/

matulak jele tepukin//

(Dukuh Siladri, puh Ginanti, hal 49 bait 8 )

Terjemahan :

Dari diri kata-katanya keluar/

kemudian kedalam diri pula kembalinya/

kalau selamat keluarnya/

kembalinya juga akan selamat/

kalau jelek keluarnya/

maka jelek pula yang akan ditemukan//

Dalam kutipan di atas nampak pengarang memberikan pengajaran kepada pembaca agar dalam mengeluarkan kata-kata hendaknya baik agar kata-kata yang diterima baik juga. Karena kata-kata yang baik akan membuat rasa nyaman bagi yang mendengarnya. Kalau dalam pergaulan sudah tercipta rasa nyaman akan tercipta rasa cinta damai.

\subsubsection{Bersahabat/ Komunikatif}

Bersahabat/komunikatif

merupakan suatu tindakan yang memperlihatkan rasa senang berbicara, bergaul, dan bekerja sama dengan orang lain. Kemampuan berkomunikasi dengan baik akan berpengaruh terhadap pergaulan, karena dengan bergaul akan bertemu dengan bermacam-macam orang dengan berbagai macam karakter, melalui hal tersebut akan memiliki banyak teman. Begitu juga dalam cerita ini tokoh sang pendeta memberikan nasehat kepada I Mudita pada waktu I Mudita mendapat kesusahan akibat ditinggalkan oleh kedua orang tuanya. Kutipan di bawah akan memperjelas amanat tersebut di atas :

Tingkahe dadi pianak/ tatuiyane buka janil da maren ngertiang kawitan/

reh mutang jiwa ring guru/

tong pragat bayah ban jinah/

buka cahil

astiti bakti anggon mayah//

(Dukuh siladri, puh Ginada, hal 19 bait 34)

Terjemahan :

Laksana menjadi seorang anak/

seperti saat ini/

jangan berhenti berbuat kebaikan

pada leluhur/

karena berhutang jiwa kepada orang tua/

tidak dapat dibayar dengan uang/

seperti kamu/

setia berbakti dipakai membayar//

\subsubsection{Gemar Membaca}

Gemar membaca merupakan kebiasaan menyediakan waktu untuk membaca berbagai bacaan yang memberikan kebajikan untuk diri sendiri. Dalam cerita ini, tokoh Ni Kusumasari jika dilihat dari sudut psykhologis, bahwa tokoh $\mathrm{Ni}$ Kusumasari sangat cerdas tentang berbagai ilmu. Kecerdasan tersebut dikarenakan oleh tingginya keingintahuan dari tokoh tersebut, sehingga harus banyak belajar dengan sering membaca berbagai macam pengetahuan yang terdapat dalam sebuah karya sastra baik sastra klasik maupun sastra tradisional. Hal itu dapat dilihat pada kutipan berikut:

Suba lami sawatara roras tanwang/

pianaknya sube kelih/

Kusumasari adanyal

sahi uruk masastral

makidung mwang makakawin/

wariga lan mantral

sami sampun kahuningin//

(Dukuh siladri, puh Durma, hal 14 bait 94)

Terjemahan: 
Sesudah kira-kira 12 tahun/

anaknya sudah besar/

Kusumasari namanya/

sering diajari ilmu sastra/

'makidung'atau 'makakawin'/

'wariga' dan 'mantra'/

semua sudah diketahui//

Dalam kutipan di atas jelas sekali nampak bahwa tokoh $\mathrm{Ni}$ Kusumasari merupakan tokoh yang gemar membaca segala macam pengetahuan. Dengan demikian, tokoh Ni Kusumasari merupakan tokoh yang sangat cerdas.

\subsubsection{Jujur}

Jujur merupakan perilaku yang didasarkan pada upaya menjadikan diri sebagai orang yang selalu dapat dipercaya baik dalam perkataan, perbuatan maupun perilaku atau tindakannya. Dalam cerita ini juga terdapat ajaran tentang kejujuran tersebut. Hal itu dapat dilihat pada kutipan berikut :

Kranan ing janma tumuwuh/

terikayane ulatil

alus mamunyi palapan/

buwine tingkah alep bakti/

darma patute mamanah/

nto prihang dadi janma/l

(Dukuh siladri, puh Ginanti, hal 48 bait 2)

Terjemahan :

Sebabnya hidup sebagai

manusia/

tiga dasar tingkah laku yang suci jalankan/

berbicara yang halus dan pelan/

tingkah laku yang halus dan bakti/

berpikirlah yang benar/

begitulah seharusnya menjadi

manusia//

Kalau diperhatikan kutipan tersebut di atas dapat disimak bahwa pengarang melalui karyanya menekankan kepada pembaca agar hidup sebagai manusia hendaknya dalam berbuat selalu waspada dan hati-hati. Begitu pula dalam berbicara hendaknya dipikirkan terlebih dahulu supaya kata-kata yang diucapkan jangan sampai menyinggung perasaan orang lain. Di samping itu salah kata-kata bukan saja akan menyinggung perasaan orang lain, akan tetapi juga dapat mendatangkan malapetaka bagi diri sendiri. Begitu pula hendaknya dengan pikiran, di dalam berpikir itu haruslah berpikir yang jujur agar tidak mendatangkan malapetaka bagi diri sendiri. Sebab kalau jalan berpikir yang jujur otomatis tingkah laku juga baik.

\subsubsection{Kerja Keras}

Kerja keras merupakan suatu perilaku yang menunjukkan upaya yang sungguh-sungguh dalam mengatasi berbagai hambatan terhadap segala permasalahan dalam kehidupan. Dalam cerita ini juga terdapat sikap tokoh I Siladri juga mengajarkan kepada anaknya agar mampu menghadapi tantang dalam hidupnya kelak. Seperti diajarkan bahwa punya tangan jangan usil agar kebenaran ditemukan. Demikian pula punya kaki agar hati-hati menjalankannya sebab kalau tersandung kita sendiri juga yang merasakan sakitnya. Begitupula punya tubuh hendaknya diperhatikan, agar menemukan keselamatan. Kutipan dibawah ini akan memperjas hal tersebut:

Ngelah lima da pati gudip/

apikin juwa nyemakang/

apang patute bakatang/

wiadin batise tindakan/

yatnahin tuwah nyalahang/

katanjung bena nahanang//

(Dukuh Siladri, puh

Smarandana, hal 27 bait 13) 
Awake patut gawenin/ apang manggih karahayuan/ da maren ngertiang awak/ waluya matatanduran/ tingkahe ngardinin awak/ yan anteng tuwi manandur/ joh para tuara mupuwang// Dukuh Siladri, puh Smarandana, hal 22 bait 14)

Terjemahan :

Punya tangan jangan usil/ pilihkanlah mengambil sesuatu/ agar kebenaran yang didapatkan/ begitu juga dalam melangkahkan kaki/

hati-hatilah melangkahkannya/ jangan asal melangkah/

kalau tersandung kita sendiri merasakan sakitnya//

Kita harus bekerja/

agar mendapatkan kesejahteraan/ janganlah bosan mendoakan diri/ bagaikan menanam tanaman/ perbuatan membuatkan diri/ kalau rajin menanam tanaman/ sudah pasti akan menghasilkan//

Kalau diperhatikan kutipan di atas pengarang memberikan pendidikan melalui tokoh I Siladri, bahwa kalau punya tangan hendaknya jangan usil pilihkanlah juga dalam mengambilkannya. Begitu pula halnya dalam melangkahkan kaki hendaknya hatihati di dalam melangkahkannya., agar nantinya tidak tersandung. Demikian juga dengan tubuh hendaknya pergunakan agar mendatangkan kesejahteraan.

Seseorang harus bekerja keras untuk mendapatkan kesejahteraan dalam hidupnya. Di samping bekerja keras juga diikuti dengan berdoa dan bersyukur agar hasil kerja dapat bermanfaat.

\subsubsection{Tanggung Jawab}

Tanggung jawab merupakan sikap dan perilaku seseorang untuk melaksanakan tugas dan kewajibannya yang seharusnya dilakukan terhadap diri sendiri, masyarakat, lingkungan alam, sosial maupun budaya, negara dan Tuhan Yang Maha Esa. Dalam cerita ini juga terdapat ajaran tanggung jawab oleh tokoh sang pendeta yang memberikan nasehat kepada I Mudita pada waktu I Mudita mendapat kesusahan akibat ditinggalkan oleh kedua orang tuanya. Kutipan di bawah akan memperjelas amanat tersebut di atas :

Tingkahe dadi pianak/

tatuiyane buka jani/

da maren ngertiang kawitan/

reh mutang jiwa ring guru/

tong pragat bayah ban jinah/

buka cahil

astiti bakti anggon mayah//

(Dukuh siladri, puh Ginada, hal 19 bait 34)

Terjemahan :

Laksana menjadi seorang anak/

seperti saat ini/

jangan berhenti berbuat kebaikan pada leluhur/

karena berhutang jiwa kepada orang tua/

tidak dapat dibayar dengan uang/ seperti kamu/

setia berbakti dipakai

membayar//

Kalau diperhatikan kutipan di atas, bahwa seorang anak hendaknya jangan sampai lupa kepada orang tua, sebab pengorbanan beliau sangat besar kepada anaknya yang tidak dapat dibayar dengan uang. Dan hanya dapat dikembalikan melalui rasa 
hormat dan bakti serta bertanggungjawab terhadap orang tua.

\subsubsection{Peduli Sosial}

Peduli sosial merupakan sikap dan tindakan yang selalu ingin memberi bantuan pada orang lain maupun pada masyarakat yang membutuhkan. Dalam cerita ini juga terdapat ajaran tentang peduli sosial yaitu tokoh Ni Kusumasari ditinjau dari susut sosial bahwa dia sangat dicintai oleh warga desanya karena tingkah lakunya baik dan jujur serta suka membantu orang lain. Hal tersebut dapat dilihat pada kutipan dibawah ini:

Pirang dina lawas ipun/ sampun ring jagat mameling / Mudita Kusumasari/

wong desane tresna sami / bahan bisane mabikas/

darma tur welasan hati//

(Dukuh siladri, puh Kinanti, hal 80 bait 57)

Terjemahan:

Setelah sekian lamanya mereka/ sudah berada di Desa Mameling/ Mudita dan Ni Kusumasari/ warga desanya semua senang / karena pandainya bertingkah/ jujur dan suka membantu/

\subsubsection{Religius}

Religius merupakan sikap dan perilaku yang patuh dalam melaksanakan ajaran agama yang dianutnya, toleran terhadap pelaksanaan ibadah agama lain dan hidup rukun dengan pemeluk agama lain. Ajaran religius juga terdapat dalam cerita ini. Aspek religius yang terdapat dalam Geguritan Dukuh Siladri adalah pada saat melakukan upacara pitra yadnya. Hal tersebut dilakukan karena masyarakat sangat religius bahwa orang sudah meninggal juga masih harus dibuatkan upacara pitra yadnya untuk mengantarkan rohnya ke alam sana. Hal tersebut dapat dilihat pada kutipan berikut :

Banjare raris ngaryanang/

len ada manyemak tiying/

buwat pacang panusungan/

lante miwah tumpang salu/

buwin ada nunas pangentas/

sada gatil

dabdab manywun daksina/

(Dukuh siladri, puh Ginada, hal 20 bait 37)

Kocap sampun mupakaral

sawane wus maci-maci/

raris nabdabang ka setral

bangbangnyane sampun puput/

sawane wus mapangentas/

luh muanil

katanem dadi abangbang//

(Dukuh siladri, puh Ginada, hal 20 bait 38 )

Terjemahan :

Warga desa segera bekerja/

ada yang mengambil bambu/

untuk usungan jenasah/

lante dan tumpang salu/

ada lagi yang memohon air suci/

sepertinya/

sudah sipa menjunjung daksina//

sesudah selesai dimohonkan berkah/

jenasahnya sudah selesai diupacarai/

kemudian jenasahnya dibawa ketempat penguburan/

liang kubur sudah digali pula/

pada jenasah diperciki air suci/

suami istri/

keduanya dimakamkan dalam satu liang//

Dalam kutipan di atas jelas sekali nampak adanya upacara pitra yadnya yaitu suatu upacara yang dilakukan untuk manusia yang telah meninggal dunia. Hal ini 
menunjukan bahwa manusia adalah mahluk religius, yaitu mahluk yang ingin mendekatkan diri pada Tuhan. Sebab Tuhan adalah asal dan kembalinya mahluk hidup.

Selain upacara pitra yadnya, dalam Geguritan Dukuh Siladri juga terdapat adanya upacara manusia yadnya yaitu pengorbanan suci yang ditujukan untuk kesempurnaan hidup manusia. Hal tersebut dapat dilihat pada kutipan berikut :

Sami pada tresna takut/ sakuhub jagat mameling/

I Mudita liang sukal

somahne bobot nambehin/ sampun magedong-gedongan/

Mudita yatna ngajahin//

(Dukuh siladri, puh

Ginanti, hal 80 bait 60)

Asaksana sampun puput/

rarene suba mabersih/

sampun matepung tawaran/

banten dapetan cumawis/

samping rarene magenah/

wong desane liu ngebagin//

(Dukuh siladri, puh Ginanti, hal 81 bait 64 )

Terjemahan :

Semua pada suka dan takut/

seluruh desa Mameling

I Mudita sangat senang/ istringa hamil menambahi/ sudah magedong-gedongan/ Mudita hati-hati melayani// Sebentar sudah selesai/ bayinya sudah dibersihkan/ sudah matepung tawaran/ banten dapetan tersedia/ di samping bayinya berada/ warga desa banyak yang menjaga//

Dalam kutipan di atas nampak bahwa sejak bayi masih berada di dalam kandungan sudah diupacarai, serta upacara tersebut dinamakan dengan upacara 'magedonggedongan'. Demikian juga saat bayi baru lahir juga dibuatkan 'tepung tawar' yaitu untuk pelengkap sajen pensucian pada waktu upacara yang dilengkapi dengan 'banten dapetan' yang dilengkapi di sampingnya. Hal ini dimaksudkan untuk selamatan bayi dan ditujukan kepada yang menjelma.

Demikianlah nilai-nilai pendidikan karakter yang terkandung dalam Geguritan Dukuh Siladri yang sangat baik dijadikan tauladan dan berperilaku dalam kehidupan bermasyarakat.

\section{SIMPULAN}

Nilai-nilai pendidikan karakter yang terkandung dalam Geguritan Dukuh Siladri adalah : 1) Rasa ingin tahu merupakan sikap dan tindakan yang selalu berupaya untuk mengetahui lebih mendalam tentang sesuatu yang dipelajarinya, dilihatnya, dirasakannya, maupun yang didengarnya. Dalam cerita ini tokoh I Siladri dengan I Made Kirti yaitu membicarakan tentang maksud I Siladri untuk menuntut ilmu kepada Empu Dibiyaja di Gunung Kawi, karena I Siladri merasa bodoh sehingga harus banyak belajar agar mampu menjalani kehidupan. 2) Rasa cinta damai merupakan sikap, perkataan dan tindakan yang menyebabkan orang lain merasa senang dan aman atas kehadiran dirinya. Untuk dapat membuat orang lain merasa nyaman, sebagai individu dalam melakukan setiap perkataan maupun perbuatan hendaknya dipikirkan matang-matang sehingga tidak menyinggung perasaan orang lain. Geguritan Dukuh Siladri dari awal sampai akhir cerita yang ditonjolkan tentang pendidikan atau ajaran-ajaran cinta damai yang patut 
dijadikan pedoman dalam kehidupan. 3) Bersahabat/komunikatif merupakan suatu tindakan yang memperlihatkan rasa senang berbicara, bergaul, dan bekerja sama dengan orang lain. Kemampuan berkomunikasi dengan baik akan berpengaruh terhadap pergaulan, karena dengan bergaul akan bertemu dengan bermacam-macam orang dengan berbagai macam karakter, melalui hal tersebut akan memiliki banyak teman. 4) Gemar membaca merupakan kebiasaan menyediakan waktu untuk membaca berbagai bacaan yang memberikan kebajikan untuk diri sendiri. Dalam cerita ini, tokoh Ni Kusumasari jika dilihat dari sudut psykhologis, bahwa tokoh Ni Kusumasari sangat cerdas tentang berbagai ilmu. Kecerdasan tersebut dikarenakan oleh tingginya keingintahuan dari tokoh tersebut, sehingga harus banyak belajar dengan sering membaca berbagai macam pengetahuan yang terdapat dalam sebuah karya sastra baik sastra klasik maupun sastra tradisional. 5) Jujur merupakan perilaku yang didasarkan pada upaya menjadikan diri sebagai orang yang selalu dapat dipercaya baik dalam perkataan, perbuatan maupun perilaku atau tindakannya. 6) Kerja keras merupakan suatu perilaku yang menunjukkan upaya yang sungguhsungguh dalam mengatasi berbagai hambatan terhadap segala permasalahan dalam kehidupan. 7) Tanggung jawab merupakan sikap dan perilaku seseorang untuk melaksanakan tugas dan kewajibannya yang seharusnya dilakukan terhadap diri sendiri, masyarakat, lingkungan alam, sosial maupun budaya, negara dan Tuhan Yang Maha Esa. 8) Peduli sosial merupakan sikap dan tindakan yang selalu ingin memberi bantuan pada orang lain maupun pada masyarakat yang membutuhkan. Dalam cerita ini juga terdapat ajaran tentang peduli sosial yaitu tokoh Ni Kusumasari ditinjau dari susut sosial bahwa dia sangat dicintai oleh warga desanya karena tingkah lakunya baik dan jujur serta suka membantu orang lain. 9) Religius merupakan sikap dan perilaku yang patuh dalam melaksanakan ajaran agama yang dianutnya, toleran terhadap pelaksanaan ibadah agama lain dan hidup rukun dengan pemeluk agama lain. Ajaran religius juga terdapat dalam cerita ini. Aspek religius yang terdapat dalam Geguritan Dukuh Siladri adalah pada saat melakukan upacara pitra yadnya. Hal tersebut dilakukan karena masyarakat sangat religius bahwa orang sudah meninggal juga masih harus dibuatkan upacara pitra yadnya untuk mengantarkan rohnya ke alam sana.

\section{DAFTAR PUSTAKA}

Agastia, Ida Bagus Gede. 1980.

"Geguritan Sebuah Bentuk Karya

Sastra Bali" Makalah yang dibawakan pada saresehan Sastra Daerah Pesta Kesenian Bali.

Ahmadi, Abu. 2001. Ilmu Pendidikan. Jakarta : Rineka Cipta.

Amiruloh Syarbini. 2012. Buku Pintar Pendidikan Karakter. Jakarta : Prima Pustaka.

Aryasa, I Wayan Madra. 1983.

Pengetahuan Karawitan Bali.

Denpasar : Departemen

Pendidikan dan Kebudayaan.

Asmaun Sahlan. 2012. Desain Pembelajaran Berbasis

Pendidikan Karakter.

Jogjakarta : AR-RUZZ MEDIA.

Djunaidi Ghoni.1982. Nilai Pendidi- 